\title{
Pelatihan Pembuatan Roti Bakar Bagi Kelompok Masyarakat di Desa Cubadak Air dan Tanjung Sabar, Pariaman
}

\author{
Arwizet Karudin $\left.{ }^{*}\right) 1$, Darmawi ${ }^{2}$ \\ 1,2Pendidikan Teknik Mesin, Teknik Mesin, Universitas Negeri Padang \\ *)Corresponding author : $\equiv$ arwizet@ft.unp.ac.id
}

(Di isi oleh editor)

Diterima 01/02/2020;

Revisi 25/03/2020;

Publish 15/04/2020

Kata kunci: roti

bakar, variasi, pembakaran, oven roti, LPG

\begin{abstract}
Abstrak
Program pelatihan ini bertujuan untuk memberikan pengetahuan dan keterampilan dalam pembuatan roti bakar bagi kelompok masyarakat dari kedua mitra yang sudah produktif secara ekonomi dan masyarakat yang berencana berusaha dalam pembuatan roti. Metode yang digunakan dalam pelatihan ini adalah memberikan pengetahuan secara teoritis kepada peserta tentang jenis, bahan dan teknik pembuatan roti, manajemen usaha, pemasaran dan keuangan dengan metode cearamah. Selain metode ceramah juga digunakan metode demonstrasi cara pembuatan dan pembakaran roti dengan oven roti berbahan bakar LPG. Hasil pelatihan memperlihatkan ada perbedaan yang signifikan pengetahuan peserta tentang jenis roti, bahan roti, teknis pembuatan roti, manajemen usaha, pemasaran dan keuangan dengan skor rata-rata sebelum dan sesudah pelatihan yakni 62,$08 ; 64,08 ; 63,58$; dan 84,$08 ; 84,50$; 81,50 . Dapat disimpulkan bahwa peserta pelatihan meningkat pengetahuannya tentang jenis dan bahan roti, pengelolaan usaha, pemasaran dan keuangan serta mampu membuat berbagai variasi roti.
\end{abstract}

\section{PENDAHULUAN}

Analisis Situasi

Usaha Mikro, Kecil dan Menengah (UMKM) adalah salah satu soku guru atau pilar perekonomian di Indonesia (Razak 2012). UMKM yang berbasis ekonomi kerakyatan telah terbukti mampu penyelamat perekonomian nasional pada saat terjadinya krisis ekonomi melanda Indonesia pada tahun 1998. UMKM secara umum lebih kuat menghadapi berbagai tantangan kondisi perekonomian di Indonesia, dibandingkan dengan industri besar (Kristiyanti 2012). Hingga kini UMKM masih tetap menjadi tumpuan bagi stabilitas perekonomian nasional, karena perannya yang dapat menciptakan kesejahteraan kepada masyarakat Indonesia.

Kementerian Koperasi dan UKM RI melaporkan bahwa secara jumlah unit, UMKM memiliki pangsa sekitar 99,99\% (62.9 juta unit) dari total keseluruhan pelaku usaha di Indonesia (Oktafia 2017). Sementara usaha besar hanya sebanyak 0,01\% atau sekitar 5400 unit. Usaha Mikro 
menyerap sekitar 107,2 juta tenaga kerja $(89,2 \%)$, Usaha Kecil 5,7 juta $(4,74 \%)$, dan Usaha Menengah 3,73 juta (3,11\%); sementara Usaha Besar menyerap sekitar 3,58 juta jiwa. Artinya secara gabungan UMKM menyerap sekitar $97 \%$ tenaga kerja nasional, sementara Usaha Besar hanya menyerap sekitar $3 \%$ dari total tenaga kerja nasional.

Ada tiga peran UMKM (Prasetyo 2008) yakni:1) sarana mengentaskan masyarakat dari jurang kemiskinan. Alasan utamanya adalah, tingginya angka penyerapan tenaga kerja oleh UMKM. 2) sarana untuk meratakan tingkat perekonomian rakyat kecil. UMKM juga memiliki peran yang sangat penting dalam pemerataan ekonomi masyarakat. UMKM memiliki lokasi di berbagai tempat. Termasuk di daerah yang jauh dari jangkauan perkembangan zaman sekalipun. 3) memberikan pemasukan devisa bagi negara. Data dari Kementerian Koperasi dan UKM di tahun 2017 menunjukkan tingginya devisa negara dari para pelaku UMKM. Angkanya mencapai Rp 88,45 miliar. Saat ini angka tersebut mengalami peningkatan hingga delapan kali lipat dibandingkan tahun 2016.

Sebagai gambaran selama tahun 1997-2006 sumbangan UMKM terhadap produk domestik bruto Indonesai telah mencapai 54-57 persen (Laily 2016). Dalam hal penyerapan tenaga kerja dalam arti menyediakan lapangan pekerjaan bagi masyarakat, UMKM telah menyumbang sekitar 96 persen (Kuncoro 2008). Dapat dikatakan bahwa UMKM punya andil yang sangat besar dalam pergerakan perekonomian dan penyediaan lapangan pekerjaan bagi rakyat Indonesia. Didasarkan oleh hal di atas, maka sudah selayaknya UKM mendapat perhatian yang lebih serius dari semua pihak atau institusi; baik pemerintah, perbankan, organisasi kemasyarakatan, para wiraswastawan dan termasuk perguruan tinggi.

Sumatera Barat adalah salah satu provinsi di Indonesia yang pertumbuh perekonomiannya banyak ditopang oleh UMKM. Menurut data statistik Sumatera Barat (2019) jumlah UMKM di daerah ini ada sebanyak 593.100. Dari jumlah tersebut, terdiri dari mikro sebanyak 531.350 atau 89,59 persen, pelaku usaha kecil sebanyak 53.431 atau 9,01 persen, pelaku usaha menengah sebanyak 7.990 atau 1,33 persen dan untuk pelaku usaha besar sebanyak 419 atau 0,007 persen (Rysya 2020).

Zirma Yusra (2019) Kepala Dinas Koperasi dan UMKM Sumatera Barat mengatakan bahwa UMKM di Sumatera Barat tumbuh 2 persen dalam setahun (Dwiko 2019). UMKM di daerah ini bergerak diberbagai bidang usaha, seperti usaha kuliner, kerajinan, industri rumah tangga, industri kecil dan pedagang kecil lainnya. Salah satu UMKM yang hingga kini masih masih cukup eksis berjalan adalah mitra Program Kemitraan Masyarakat (PKM) kami saat ini.

UMKM di Kota Pariaman pada tahun 2018 berjumlah 7.065 yang tersebar di empat kecamatan dengan jumlah populasi terbesar terdapat pada kecamatan Pariaman Tengah sebanyak 2.852 UMKM (Hardianto and Rianti, 2019). Banyaknya UKM di Kota Pariaman membuktikan bahwa peningkatan pertumbuhan UMKM dari tahun ke tahun mengalami peningkatan baik dari segi kuantitas maupun dari segi kualitas UMKM. UMKM di daerah ini banyak bergerak dibidang kuliner, industri rumah tangga berupa industri mie, kerupuk, ladu, roti manis (Kodrat 2011). Dua dari UMKM yang hingga kini masih masih cukup eksis berjalan adalah menjadi mitra Program Kemitraan Masyarakat (PKM) ini.

Khalayak sasaran pada program ini adalah masyarakat yang produktif secara ekonomi (usaha mikro) dan masyarakat yang berhasrat untuk produktif secara ekonomi. Mitra pertama dari program PKM ini yakni Usaha Pembuatan Roti Bakar Mekar Sari berada di Desa Cubadak Air. Usaha Roti Bakar Mekar Sari ini di pimpin oleh Bapak Syafril yang berusia 59 tahun. Bapak Syafril telah lama bergerak dalam pembuatan roti bakar manis, lebih dari 30 tahun. Jumlah pekerja tetap pada Usaha Roti Mekar Sari ada 7 orang, 4 orang lelaki dan 3 orang perempuan. Usaha Roti ini ini masih bersifat usaha rumah tangga, sehingga sebagian besar pekerjanya adalah masih ada hubungan kekeluargaan. Karena keterbatasan alat maka perusahaan ini hanya mampu menghabiskan $100 \mathrm{~kg}$ tepung terigu dalam satu hari kerja. Luas lahan untuk Usaha Roti Bakar Mekar Sari ada sekitar $320 \mathrm{~m}^{2}$ dan berjarak 5 km dari Kota Pariaman. 


\section{Suluah Bendang: Jurnal Ilmiah Pengabdian Kepada Masyarakat}

Vol.20, No.2, 2020

Arwizet Karudin, Darmawi

Mitra kedua dari program PKM ini adalah Usaha Pembuatan Roti Bakar Pesisir Minang berada di Desa Tanjung Sabar. Usaha Roti Bakar Pesisir Minang ini di pimpin oleh Ibu Kasmawati. Beliau berusia 43 tahun berjenis kelamin perempuan. Pekerja pada industri roti Pesisir Minang adalah sebanyak 9 orang, 5 orang lelaki dan 4 orang perempuan. Luas lahan untuk perusahaan roti pesisir minang 336 meter persegi dan berjarak $3 \mathrm{~km}$ dari Kota Pariaman. Perusahaan Roti Pesisir Minang dalam satu hari kerja bisa menghabiskan $150 \mathrm{~kg}$ tepung terigu. Hampir sama dengan usaha roti bakar mekar sari di desa Cuabadak Air, usaha roti bakar Pesisir Minang juga masih disebut usaha keluarga, sebagian besar pekerjanya masih ada hubungan kekeluargaan.

Permasalahan kedua mitra dapat dibedakan atas beberapa aspek yaitu: pertama permasalahan dari aspek produksi yakni terkait dengan peralatan dan perlengkapan produksi tidak memadai terutama pengaduk adonan roti dan tungku pembakar roti. Tungku pembakar roti yang digunakan masih berbentuk tradisional yang terbuat dari bata yang diplester menyerupai goa dengan lobang masuk roti berupa pintu dengan ukuran $0,8 \mathrm{~m}$ x 1,60 m. Sumber energi berasal dari bahan bakar kayu dalam jumlah tertentu.

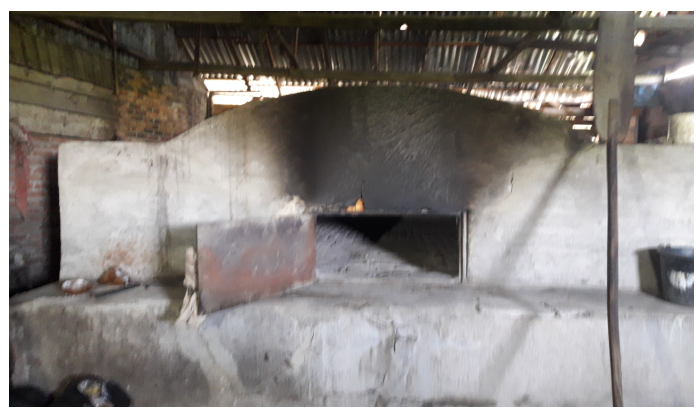

Gambar 1. Bentuk tungku pembakaran roti bakar dari mitra

Menurut hemat tim PKM bahwa model pembakaran roti menggunakan tungku roti seperti ini mempunyai beberapa kelemahan yaitu: a) tingkat roti kematangan roti yang didapatkan tidak bisa sama atau seragam, b) suasana kerja yang panas dan sangat membahayakan bagi pekerja, c) tidak hygienes, dan d) merusak lingkungan.

Dari sisi produksi roti bakar yang dihasilkan terlihat juga kurang bervariasi dari segi bentuk dan rasa. Roti bakar produksi kedua mitra ini masih belum bervariasi hal ini ditandai dengan produk yang dihasilkan mempunyai rasa yang hampir sama. Roti bakar yang dihasilkan variasinya masih terbatas seperti roti manis bakar inti kelapa, roti sandwich, roti kering bakar diberi gula. Padahal masih banyak variasi roti bakar yang dapat diproduksi oleh perusahaan ini jika diberi pengetahuan tentang berbagai roti bakar dan teknologi yang digunakan sehingga penghasilan mitra menjadi meningkat secara signifikan. Permasalahan kedua yaitu aspek manajemen yang terkait dengan masalah pengelolaan usaha, pemasaran dan keuangan.

\section{Solusi dan Target}

\section{Solusi Permasalahan}

Masalah-masalah yang didapatkan pada kedua mitra pada program pelatihan ini digolongkan ke dalam dua aspek permasalahan yaitu aspek produksi, aspek manajemen dan aspek pemasaran. Guna mengatasi permasalah kedua mitra, maka solusi yang ditawarkan adalah sebagai berikut:

a) pengadaan peralatan produksi berupa mesin pembakar roti menggunakan model pembakaran truck dryer top up air flow dengan bahan bakar LPG.

b) pelatihan pembuatan roti bakar yang bervariasi dari sisi bentuk dan rasa. 
c) pelatihan manajemen pengelolaan usaha, pemasaran dan adminstrasi keuangan.

\section{Rencana Kegiatan Pengabdian}

Rencana kegiatan pelatihan pembuatan roti bakar bagi kelompok masyarakat pembuat roti bakar di desa Cubadak Air dan desa Tanjung Sabar ini direncanakan sebagai berikut:

a) mengadakan mesin pemanggang roti berbentuk oven roti model pembakaran truck dryer top up air flow dengan bahan bakar LPG.

a) pemberian secara teoritis pengetahuan tentang jenis-jenis roti, bahan pembuat roti dan teknik pembuatan roti.

c) demonstrasi praktek pembuatan roti oleh instruktur. Pada metode demontrarasi ini instruktur memperagakan cara membuat roti mulai dari penentuan jenis roti yang akan dibuat, pemilihan bahan yang digunakan, proses pengadukan adonan, pencetakan roti, peragian dan permentasi roti, pemberian inti dan topping roti.

d) praktek pembuatan roti secara berkelompok oleh peserta pelatihan.

e) praktek pemanggangan roti hingga roti siap untuk dikonsumsi.

e) pemberian pengetahuan tentang teknis pengelolaan usaha, pemasaran dan adminsitrasi keuangan.

\section{Prosedur dan Target Kegiatan}

Prosedur kegiatan yang direncanakan dalam program pelatihan pembuatan roti bakar di desa Cubadak Air dan Tanjung Sabar ini adalah: a) rekruitmen peserta pelatihan, b) melaksankana kegiatan pelatihan, c) evaluasi kegiatan sebagai masukan untuk memperbaiki kegiatan serupa pada masa yang akan datang, sekaligus untuk menilai apakah proses pelatihan sudah memenuhi target yang direncanakan. Beberapa kegiatan evaluasi yang dilakukan adalah mengukur tingkat pencapaian pemahaman peserta terhadap materi pelatihan melalui posttest yang dilakukan diakhir kegiatan dan kemampuan semua peserta membuat roti bakar sesuai yang direncanakan.

Target dari kegiatan ini adalah: a) meningkatnya pengetahuan peserta tentang berbagai jenis roti, bahan pembuat roti, teknik membuat roti, pengelolaan usaha, pemasaran dan administrasi keuangan; b) peserta mampu melakukan praktek pembuatan roti dan pemanggangan roti dengan baik; c) dihasilkannya berbagai jenis roti dengan bentuk dan rasa yang berbeda; d) lahirnya wirausaha baru dalam usaha pembuatan roti yang lebih variatif dari segi bentuk dan rasa; e) terjadinya desiminasi keilmuan tentang pembuatan roti oleh peserta pelatihan ke masyarakat lainnya di desa ini dan desa lainnya; f) publikasi ilmiah tentang pelatihan pembuatan roti melalui artikel ilmiah, media massa cetak dan media online.

\section{METODE PELAKSANAAN}

Metode pelakanaan Program Kemitraan Masyarakat (PKM) ini dilakukan sebagai berikut:

\section{Tempat dan Waktu}

Tempat pelaksanaan Program Kemitraan Masyarakat (PKM) dengan judul pelatihan pembuatan roti bakar bagi kelompok masyarakat di desa Cubadak Air dan Tanjung Sabar, Pariaman Utara, Kota Pariaman dari 1 Agustus hingga 8 September 2019.

\section{Khalayak Sasaran}

Pemilihan khalayak sasaran yang dijadikan sebagai mitra diawali oleh survey atau observasi yang dilakukan oleh tim pengabdian pada beberapa usaha pembuatan roti bakar di Kota Pariaman dan Kabupaten Padang Pariaman, Sumatera Barat pada awal bulan April 2019. Data yang didapatkan dari hasil observasi dinalisis sedemikian rupa maka dilanjutkan dengan memilih mitra yang berminat dan layak bekerjasama dengan tim pengabdian. Setelah melalui berbagai pertimbangan kelayakan, maka sasaran pada kegiatan pengabdian ini adalah Usaha 
Pembuatan Roti Bakar Manis Mekar Sari di Desa Cubadak Air dan Usaha Roti Bakar Manis Pesisir Minang di Desa Tanjung Sabar, Pariaman Utara, Kota Pariaman, Sumatera Barat.

Kedua mitra dari kegiatan ini dijadikan kelompok masyarakat yang produktif secara ekonomi. Selain dua mitra ini yang menjadi peserta pelatihan juga dari kelompok ibu-ibu muda di desa Cubadak Air dan Tanjung Sabar yang belum produktif secara ekonomi tetapi berhasrat kuat untuk mau berwirasuaha di bidang pembuatan roti bakar manis.

\section{Metode Pengabdian adalah: \\ Metode pengabdian yang dilakukan program kemitraan masyarakat (PKM) ini}

\section{a. Pengadaan Peralatan Produksi}

Perlatan produksi utama pada mitra adalah berupa mesin pembakar roti menggunakan model pembakaran Truck Dryer Top Up Air Flow dengan berbahan bakar LPG. Oven pembakar roti ini diharapkan dapat menjadi pengganti model tungku roti yang berbahan bakar kayu yang selama ini digunakan oleh mitra.

\section{Pelatihan Pembuatan Roti Bakar dengan Berbagai Varasi Bentuk dan Rasa}

Pelatihan pembuatan roti bakar bagi kelompok masyarakat di desa Cubadak Air dan

Tanjung Sabar ini dilakukan melalui tahapan-tahapan sebagai berikut:

a) tahap pertama yaitu pemberian secara teoritis kepada peserta pengetahuan tentang jenisjenis roti, bahan pembuat roti dan teknik pembuatan roti.

b) tahap kedua yaitu mendemonstrasikan praktek pembuatan roti oleh instruktur. Pada tahap ini instruktur mencotohkan membuat suatu jenis roti dengan rasa tertentu. Instruktur melakukan pengidentifikasian bahan pembuatan roti, pengadukan adonan roti secara manual dan mixer, peragian/permentasi roti, pemberian inti/topping roti. Dalam tahap ini peserta pelatihan memperhatikan apa yang dilakukan oleh instruktur dan ikut mengambilkan bahanbahan yang diperlukan oleh instruktur. Peserta juga dapat bertanya jika ada sesuatu yang kurang dipahami terutama langkah-langkah dalam pembuatan roti bakar.

c) tahap ketiga yaitu praktek pembuatan roti bakar oleh peserta yang dibentuk dalam tiga kelompok. Tiap kelompok beranggotakan 4 orang dan ditugaskan membuat satu jenis bentuk roti dan beberapa variasi rasa. Pada tahap ini setiap kelompok diberi tugas oleh instruktur membuat satu jenis bentuk roti dan beberapa variasi rasa seperi keju, strawberry, blue berry, coklat dan sebagainya. Mulai dari awal proses penimbangan tepung terigu, gula, susu bubuk, garam dan sebagainya. Dialnjutkan dengan proses pengadukan adonan, proses permentasi dan pemberian topping roti dengan berbagai variasi rasa. Setelah proses permentasi dan pemberian topping roti, maka dilanjutkan dengan pembakaran roti.

d) tahap keempat yaitu tahap pembakaran roti. Pembekaaran roti dilakukan dalam oven roti berbahan bakar LPG. Oven pembakar roti menggunakan model pembakaran Truck Dryer Top Up Air Flow dengan berbahan bakar LPG. Oven pembakar roti ini terdiri dari 2 tingkat dengan kapasitas sekali pembakaran roti 50 buah roti. Oven roti ini diharapkan dapat menjadi pengganti model tungku roti yang berbahan bakar kayu yang selama ini digunakan oleh mitra.

3. Pemberian Bekal Pengetahuan Tentang Pengelolaan Usaha, Teknik Pemasaran dan Pengelolaan Administrasi Keuangan

Peserta diberikan bekal pengetahuan secara teoritik tentang pengelolaan usaha, teknik pemasaran produk dan pengelolaan administrasi keuangan yang benar oleh instruktur. Pengelolaan usaha difokuskan kepada usaha roti bakar manis. Sedang teknik pemasaran diajarkan bagaimana memasarkan produk yang sudah dibuat mulai dari pengantarkan produk ke pasar-pasar dan warung penjual roti, kartu nama dan plang nama tempat usaha roti bakar. 
Sedangkan untuk pengelolaan administrasi keuangan peserta diajarkan bagaimana membuat pembukaan keuangan yang baik terutama uang masuk dan uang keluar yang tercatat sedemikian rupa, sehinga csh flow keuangan industry dapat dilihat dan diketahui dengan baik.

\section{Indikator Keberhasilan}

Indikator keberhasilan dari program pelatihan ini dikaitkan dengan hasil yang dicapai pada program pelatihan pembuatan roti bakar bagi kelompok masyarakat usaha pembuatan roti bakar manis di desa cubadak air dan desa tanjung sabar, kecamatan pariaman utara, kota pariaman sudah sesuai dengan tujuan dari program ini. Hasil yang dapat dicapai dari pelaksanaan kegiatan PKM dapat diuraikan sebagai berikut:

\section{Tersedianya Beberapa Alat Produksi yang Diperlukan pada Pelatihan Pembuatan Roti Bakar Manis: Oven Gas, Mixer dan Peralatan Pendukung Lainnya}

Alat produksi roti bakar manis yang utama diperlukan dalam proses pembuatan roti adalah oven gas LPG, mixer, timbangan dan beberapa peralatan pendukung lainnya seperti baskom dan nampan stainlessteel, rolling pan, plastik roti dan plastik wrap.

Oven gas LPG adalah salah satu peralatan yang sangat diperlukan oleh mitra program dalam membakar roti. Oven gas LPG dipesan dari Cawang Jakarta sebanyak 2 unit yang berukuran panjang $0,80 \mathrm{~m}$ dan lebar $0,44 \mathrm{~m}$. Oven gas LPG ini terdiri dari dua tingkat dan mempunyai kapasitas roti sekali proses pembakaran 50-60 buah roti berukuran 30-40 gr. Oven ini mempunyai loyang tempat pembakaran roti sebanyak 4 unit ukuran kecil atau 2 unit yang berukuran besar.

Untuk proses pembakaran pada oven gas ini, bisa digunakan tabung gas LPG berukuran $12 \mathrm{~kg}$ atau tabung gas LPG $5 \mathrm{~kg}$. Mixer adonan roti adalah alat yang sangat penting dalam pembuatan roti. Mixer adonan roti berfungsi untuk mengaduk adonan roti setelah dilakukan pencampuran bahan-bahan pembuat roti. Mixer adonan roti yang diadakan adalah mixer berkapsitas $1 \mathrm{~kg}$ adonan sekali buat. Mixer ini mempunyak tiga buah tipe tangkai pengaduk, dengan putaran lambat (slow speed), keepatan sedang (midle speed) dan kecepatan cepat (fast speed).
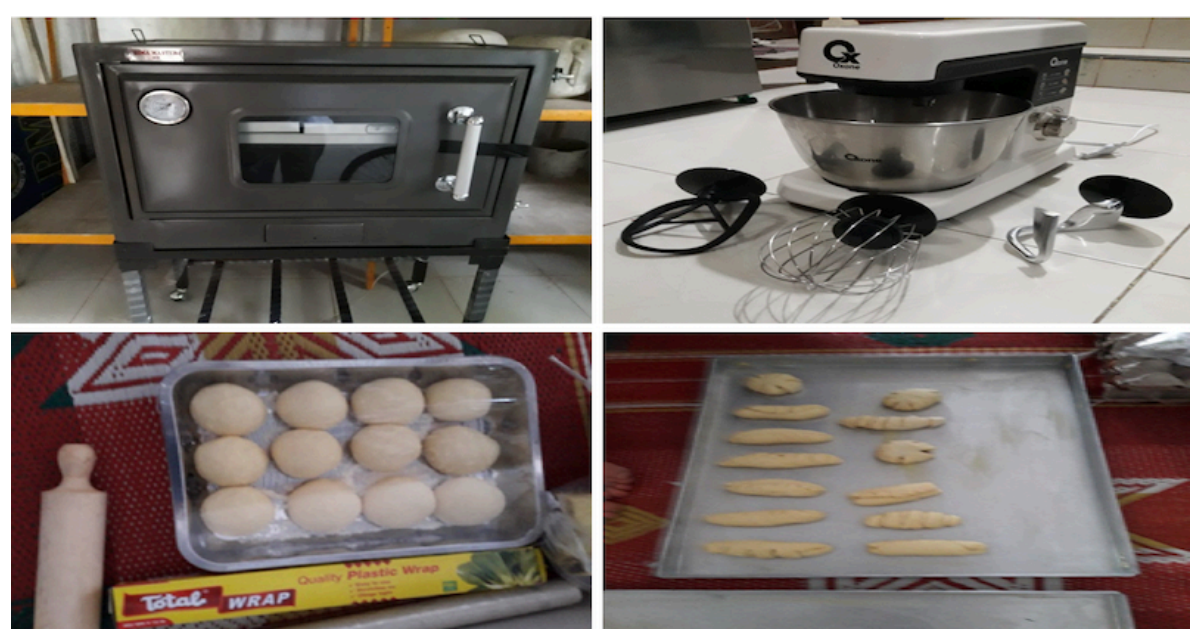

Gambar 2. Peralatan yang digunakan pada saat pelatihan pembuatan roti bakar manis

Selain peralatan utama di atas, maka pada pelatihan ini juga didukung oleh beberapa peralatan lainnya seperti: timbangan digital, ayakan tepung, rolling pan, loyang, baskom stainlessteel, nampan stainlessteel dan sebagainya. 


\section{Suluah Bendang: Jurnal Ilmiah Pengabdian Kepada Masyarakat}

\section{Terlaksananya Pelatihan Pembuatan Roti Bakar}

Instruktur pada pelatihan pembuatan roti bakar adalah Sdri. Vinny Aprilia, S.Pd. seorang praktisi pembuat roti dan alumni dari Universitas Negeri Padang. Saudari Vinny Aprilia, S.Pd sejak masih masih duduk ditingkat Sekolah Menengah Kejuruan (SMK) sudah aktif dalam pelatihan-pelatihan tentang pembuatan roti dan kue, ditambah lagi dari ilmu yang beliau dapatkan selama di bangku perkuliahan. Sdri. Vinny Aprilia, S.Pd juga sudah pernah bekerja/magang di berbagai hotel di Padang dan luar Kota Padang. Sejak selagi masih duduk dibangku perkuliahan tahun 2014 Sdri. Vinny Aprilia, S.Pd sudah membuka usaha pembuatan roti bakar manis.

Pada awal pelatihan instruktur memberikan teori tentang jenis roti dan bahan roti. Pemberian teori dengan metode ceramah, ditujukan agar peserta pelatihan memiliki pengetahuan yang baik tentang jenis-jenis roti, alat dan bahan yang diperlukan untuk pembuatan roti bakar. Selama pemberian teori tetang jenis roti dan bahan pembuatan roti, para peserta memperhatikan, mencatat dan bertanya jika ada sesuatu yang kurang dipahami oleh peserta.

Selesai pemberian teori, maka acara pelatihan dilanjutkan dengan demmontrasi praktek pelatihan pembuatan roti bakar. Selama demonstrasi praktek peserta melihat dan memperhatikan cara menimbang bahan-bahan pembuat roti dan mencatat ukuranya. Langkah dalam pembuatan roti di awali dengan mencampur semua bahan menjadi suatu adonan roti dimulai dari tepung terigu tinggi protein (tepung terigu merk cakra), ditambah gula, air, garam, fermifan dan lainnya lalu dicampur (mixer) sedemikian rupa menggunakan mesin mixer Ozone kapasitas $1 \mathrm{~kg}$. Setelah itu adonan tersebut diaggap sudah homogen (kalis), maka adonan tersebut ditimbang dengan massa tertentu (bisa 30 gr, 40 gr dan 50 gr) lalu dibulatkan dan diletakkan dalam baskom stainlessteel. Baskom stainlessteel ini diberi penutup plastik wrap untuk menjaga temperatur pada adonan guna mempercepat proses fermentasi bagi adonan.
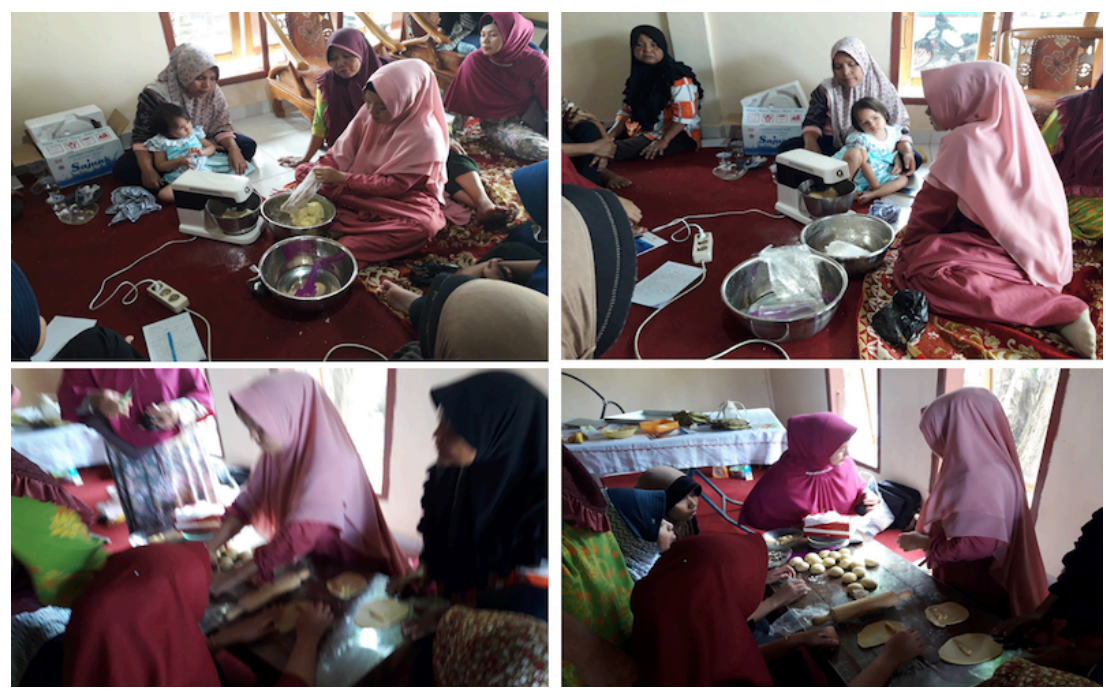

Gambar 3. Instruktur mendemontasrikan praktek pembuatan roti bakar

Selama demonstarsi praktek pembuatan roti bakar, seluruh peserta dengan serius memperhatikan, bertanya dan membantu instruktur dalam praktek pembuatan roti bakar 
tersebut. Setelah demontrasi praktek pembuatan roti diperlihatkan oleh instruktur selanjutnya, peserta dibagi atas 3 kelompok yang beraggotakan 4 orang. Masing-masingmasing kelompok membuat satu jenis bentuk roti dengan berbagai bervariasi rasanya. Berikut adalah aktivitas masing-masing kelompok peserta dalam membuat satu jenis roti yang diminta oleh instruktur.

Awal pertama yang dilakukan oleh masing-masing kelompok adalah mengidentifikasi bahan-bahan pembuat roti yang diperlukan, lalu mengaduknya secara manual dan dengan mixer sampai adonan roti tercampur secara homogen atau kalis. Setelah adonan menjadi homogen atau kalis dilanjutkan dengan mendiamkan selama lebih kurang 30 menit adonan sudah mulai mengembang. Selanjutnya adonan dibentuk menjadi macam-macam bentuk roti yang bulat, lonjong dengan sesuai dengan ukuran yang dinginkan missal 30 gr, 40 gr, dan 50 gr.
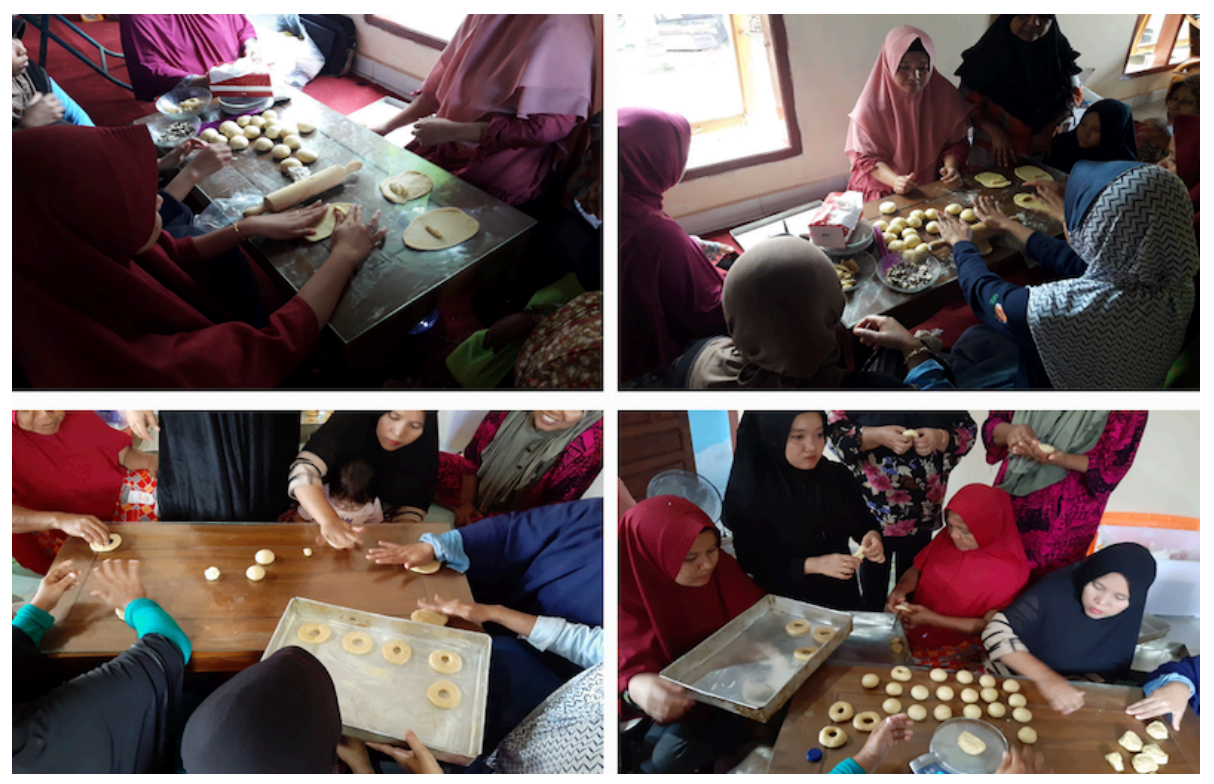

Gambar 4. Peserta sedang melakukan pembentukan roti dari adonan

Adonan yang telah dibentuk menjadi bentuk roti, lalu diberi inti roti dari selai dari nenas, coklat, strawberry, blue berry, lain-lainnya. Selanjutnya didiamkan dalam ruang bertemperatur agak tinggi agar proses permentasi atau pengembangan roti dapat kembang secara baik.

Pada pelatihan ini proses permentasi dilakukan dalam nampan stainlessteel yang ditutup dengan plastik wrap selama lebih kurang 2 jam. Adonan yang telah selesai di fermentasi selama lebih kurang 2 jam diberi toping roti sesuai toping roti yang diinginkan seperti mises, keju, coklat, atau olesan kuning telur. Setelah tahapan ini selesai, maka roti siap untuk dibakar dalam oven gas.

Oven ini berbahan LPG yang diatur sedemikian rupa. Mula-mula oven dihidupkan lebih dahulu sebelum loyang roti dimasukan ke dalam oven, biarkan agar temperatur ruang oven mencapai $180^{\circ} \mathrm{C}$. Setelah suhu mencapai $180^{\circ} \mathrm{C}$, barulah loyang roti dimasukkan ke dalam oven. Lama pembakaran roti lebih kurang 20 menit, lalu loyang dikeluarkan dan roti sudah matang. Proses pembakaran roti dalam oven roti berbahan bakar LPG dapat berlangsung dengan baik. Temperatur oven dapat terpantau dengan karena ada alat ukur temperature 
Thermostate. Untuk mengontrol panas masuk oven dapat diatur melalui control regulator LPG yang ada pada ujung selang LPG.

Roti dibakar dalam oven roti bertemperatur $180^{\circ} \mathrm{C}$ selama lebih kuran 15 menit. Hasil dari praktek pembuatan roti pada masing-masing kelompok terdiri dari berbagai bentuk dan rasa. Bentuk roti hasil pelatihan berupa roti bakar manis biasa, roti 0 , dan roti pizza.
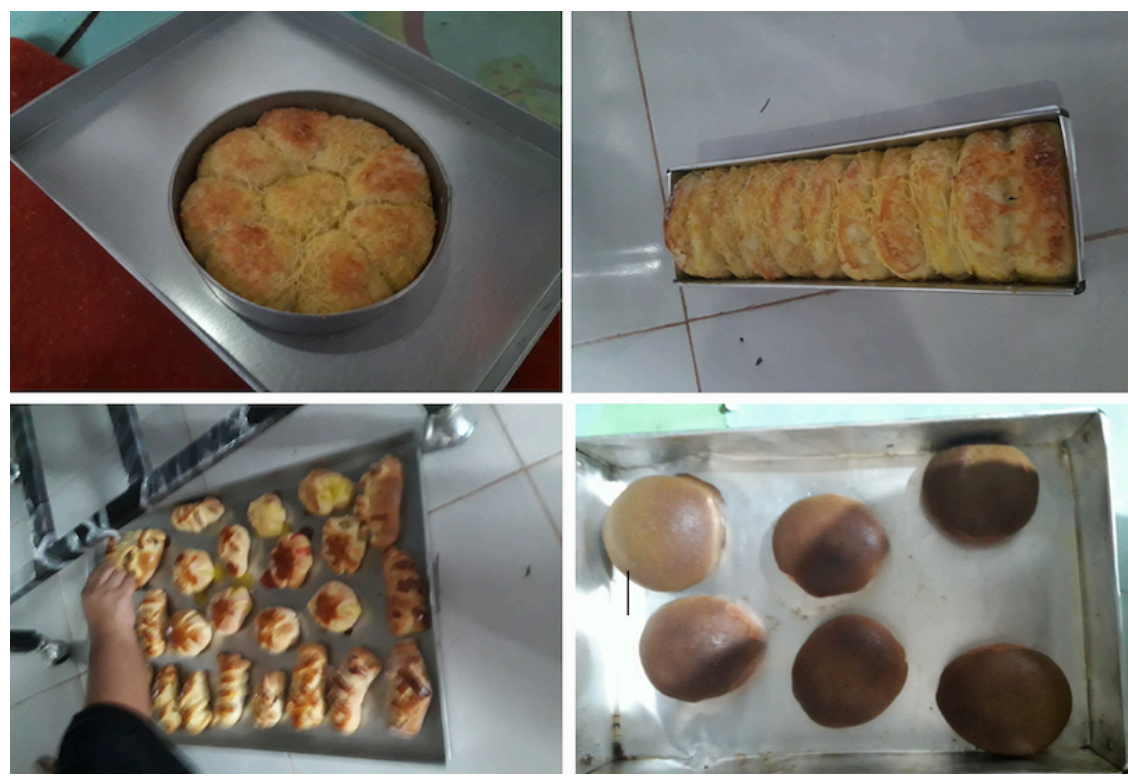

Gambar 5. Roti dibakar dalam oven roti berbahan bakar LPG

\section{Pemberian Pengetahuan tentang Pengelolaan Usaha, Pemasaran dan Administrasi Keuangan}

Menggunakan metode ceramah peserta diberikan pengetahuan tentang pengelolaan usaha khususnya usaha pembuatan roti. Peserta juga diberikan pengetahuan tentang teknik pemasaran dan administrasi keuangan. Teknik pemasaran disarankan kepada mitra agar membuat plang nama, kartu nama dan promosi dengan media cetak dan media online. Seangkan dalam administrasi keuangan peserta diajarkan bagaiman membuat pembukaan keuangan yang baik, sehingga cah flow keuangan perusahaan dapat tercatat dengan baik.

\section{Peningkatan Pengetahuan dan Keterampilan Peserta}

Hasil pengukuran yang dilakukan oleh Program Kemitraan masyarakat (PKM) Kelompok Masyarakat Usaha Pembuatan Roti Bakar Manis kepada peserta pelatihan dengan cara memberikan test kecil dan pengamatan. Kepada setiap peserta diberikan nilai (score) tertentu sesuai dengan pengamatan.

Dari gambar 6 dan 7 terdapat perbedaan yang cukup signifikan pengetahuan peserta tentang roti, teknis pembuatan roti, pengelolaan usaha roti, pengelolaan keuangan dan pemasaran sebelum dan sesudah pelatihan. 


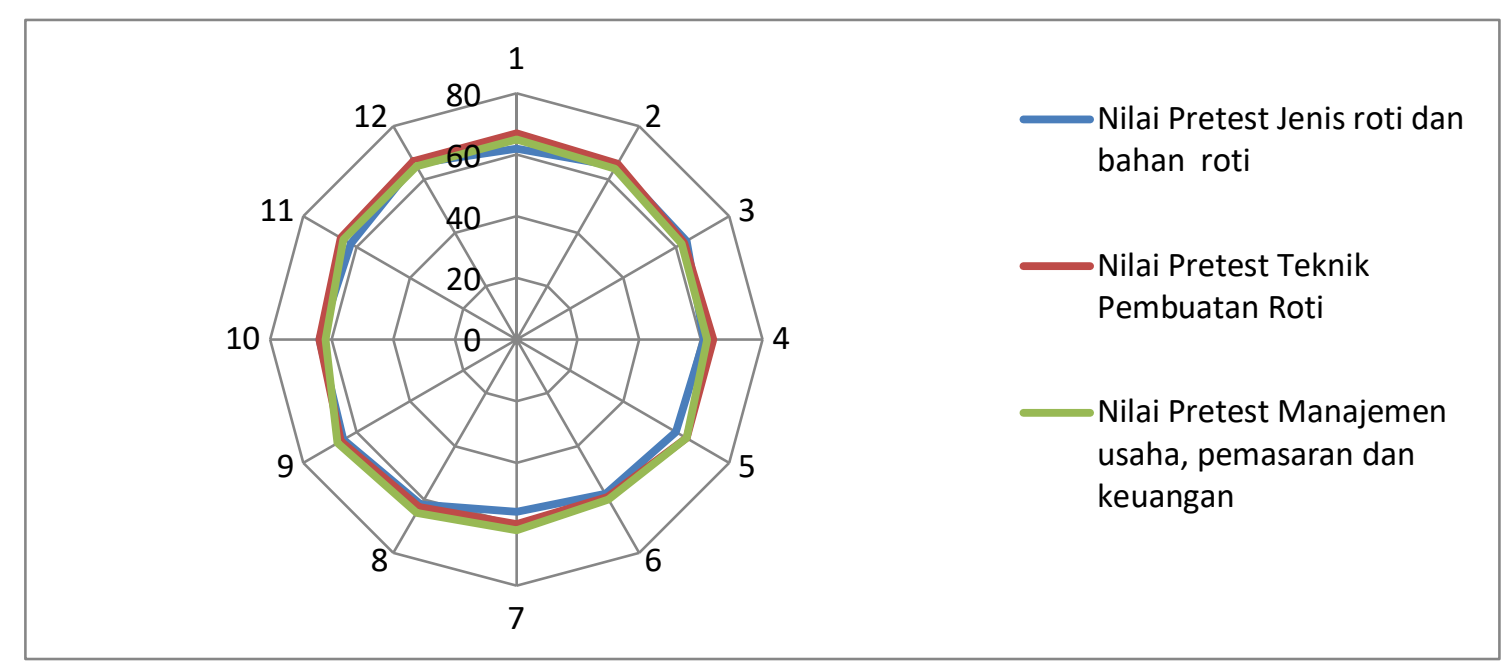

Gambar 6. Hasil pretest peserta sebelum dilakukan pelatihan

Dari gambar dapat dilihat bahwa sebelum dilakukan pelatihan (pretest) maka tingkat pengetahuan peserta tentang jenis roti, bahan roti, teknik pembuatan roti, pengelolaan usaha, pemasaran dan adminstrasi keuangan jauh masih rendah yakni 62,08; 64,08; 63,58. Hal ini dapat dimaklumi karena rata-rata peserta pelatihan belum banyak pengetahuannya tentang roti, baik mengenai jenis roti, bahan dan teknis pembuatan roti. Begitu juga tentang teknis pengeloaan usaha, pemasaran dan administrasi keuangan.

Hal ini dapat dipahami karena sebagian peserta belumlah praktisi dalam hal pembuatan roti. Skor tertinggi dilihat dapat dicapai dari peserta pelatihan yang berasal dari kelompok masyarakat berasal dari mitra khalayak sasarana. Mereka setiap hari sudah bergelut dengan roti dan pembuatan roti. Sedangkan setelah diberikan pelatihan maka terjadi peningkatan pengetahuan dan keterampilan peserta dalam hal pembuatan roti, pengelolaan usaha, pemasaran dan keuangan seperti terlihat pada gambar di bawah ini.

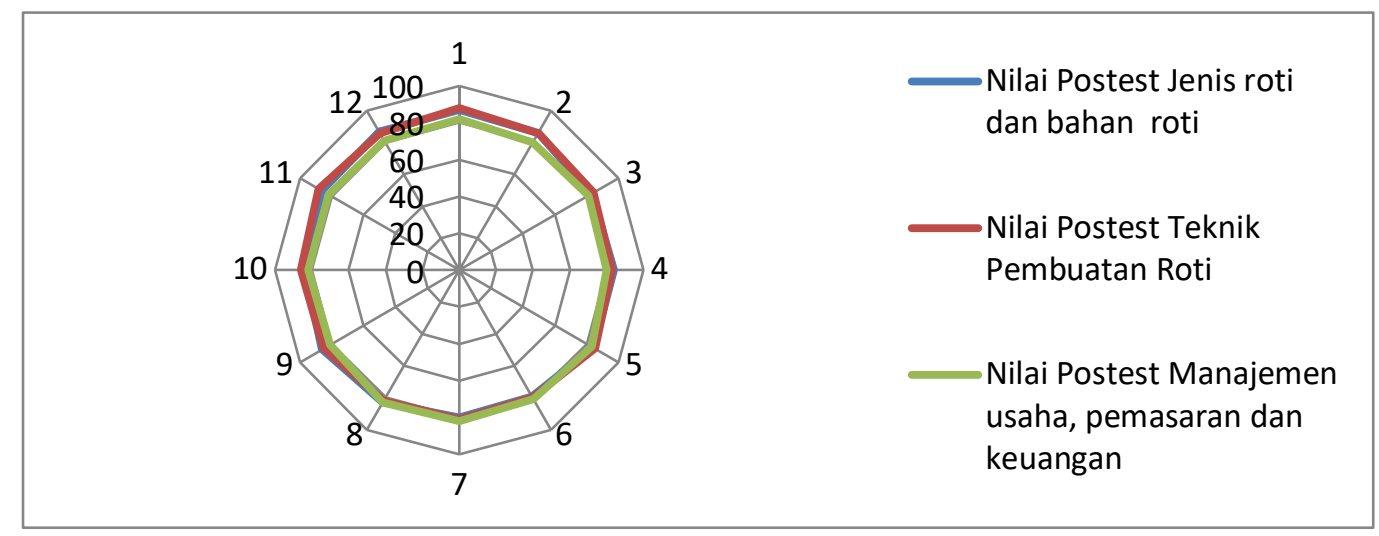

Gambar 7. Nilai pengetahuan peserta tentang roti setelah pelatihan

Dari gambar 6 dan 7 terdapat perbedaan yang cukup signifikan pengetahuan peserta tentang jenis roti, bahan roti, teknis pembuatan roti, manajemen usaha, pemasaran dan keuangan dengan skor rata-rata sebelum dan sesudah pelatihan yakni 62,08; 64,08; 63,58; dan 84,08; 84,50; 81,50. 


\section{Suluah Bendang: Jurnal Ilmiah Pengabdian Kepada Masyarakat}

\section{Metode Evaluasi}

Evaluasi kegiatan pelatihan dilakukan untuk mendapatkan masukan guna memperbaiki kegiatan serupa pada masa yang akan datang, sekaligus untuk menilai apakah proses pelatihan sudah memenuhi target yang direncanakan. Beberapa kegiatan evaluasi yang dilakukan adalah mengukur tingkat pencapaian pemahaman peserta terhadap materi pelatihan melalui postest yang dilakukan diakhir kegiatan dan kemampuan semua peserta membuat roti bakar sesuai yang direncanakan. Selanjutnya evaluasi yang juga dilakukan adalah melakukan pengontrolan secara bertahap terhadap pelaksanaan program tersebut, dengan tujuan apabila terdapat kesulitankesulitan yang dialami mitra misalnya gangguan mesin pembakar roti, pemahaman membuat laporan keuangan dan pemasaran masih ada kesulitan, maka tim pengabdi akan segera membantu mitra mencari solusinya.

Proses keberlanjutan program pelatihan yang telah diberikan kepada kelompok masyarakat terutama mitra Program Kemitraan Masyarakat melalui pemantauan berkala dan pendekatan persuasive agar selain mitra kelompok masyarakat yang ikut berlatih juga didorong agar mau memulai usaha pembuatan roti bakar manis, untuk dijual kepada masyarakat sekitar. Jika hal ini terwujud maka tentu akan terjadi lompatan peruabahan ekonomi ditengah-tengah masyarakat. Sekaligus juga dapat membuaka lapangan kerja bagi masyarakat lainnya.

\section{Daftar Pustaka}

Astawan , M. 2004. Kandungan Serat dan Gizi pada Roti Ungguli Mie dan Nasi. Diakses tanggal 15 September 2018. http://www.gizi.net

Bogasari. 2003. Resep Roti Manis. Diakses tanggal 19 Agustus 2018.

http://www.bogasari.com/produk/aplikasi-resep.aspx?a=7

Bogasari. 2010. Pengolahan Roti. Arsip Bogasari Baking Center. Palembang.

Fitasari, E. 2009. Pengaruh Tingkat Penambahan Tepung Terigu Terhadap Kadar Air, Kadar Lemak, Kadar Protein, Mikrostruktur, dan Mutu Organoleptik

Kristiyanti, Mariana. 2012. "Peran Strategis Usaha Kecil Menengah (UKM) Dalam Pembangunan Nasional." Majalah Ilmiah Informatika 3(1):63-89.

Kuncoro, Mudradjad. 2008. "Strategi Pengembangan Pasar Modern Dan Tradisional." Kadin Indonesia.

Koswara, S. 2009. Teknologi Pengolahan Roti. Diakses pada 26 Maret 2014. http://tekpan.unimus.ac.id/wp-content/uploads/07/Teknologi-Roti-Teori- danPraktek.pdf.

Mudjajanto, E.S. dan L. N. Yulianti. 2010. Membuat Aneka Roti. Penebar Swadaya. Jakarta

Laily, Nichlatul. 2016. "Analisis Pengaruh Perkembangan Usaha Kecil Menengah (Ukm) Terhadap Pertumbuhan Produk Domestik Regional Bruto (Pdrb)." Jurnal Pendidikan Ekonomi (JUPE) 4(3).

Oktafia, Renny. 2017. “Percepatan Pertumbuhan Usaha Mikro, Kecil Dan Menengah (Umkm) Melalui Perkuatan Lembaga Keuangan Mikro Syariah (Lkms) Di Jawa Timur." Pp. 85-92 in Proceedings of Annual Conference for Muslim Scholars.

Prasetyo, P. Eko. 2008. "Peran Usaha Mikro Kecil Dan Menengah (Umkm) Dalam Kebijakan Penanggulangan Kemiskinan Dan Pengangguran.” Akmenika Upy 2(1):p1-13.

Razak, Razak. 2012. "Ekonomi Koperasi Dan UKM.” Malang, Universitas Negeri Malang. 
Rysya, Hariani. 2020. "Analisis Pengaruh Innovation Terhadap Persepsi Financial Performance (Pada Umkm Industri Kuliner Di Kota Padang Tahun 2019)." Phd Thesis, Universitas Andalas. 